Nationalities Papers is the leading journal on nationalism, ethnicity, ethnic conflict and national identity in Central Europe, the Balkans, the former Soviet Union, the Caucasus, the Turkic world and Central Eurasia. Furthermore, the journal also publishes contributions on theories of nationalism, comparative studies of nationalism, and trans- and supranational aspects of interethnic relations and national identity. The journal publishes timely, high quality articles from a variety of disciplines, including history, political science, sociology, anthropology, and literature.

Nationalities Papers is the journal of the Association for the Study of Nationalities, bringing together scholars worldwide working on nationalism and ethnicity, Central and Eastern Europe, the Balkans and Eurasia.

All articles have undergone rigorous peer review, based on initial editor screening and double-blind refereeing by a minimum of two anonymous referees.

The journal welcomes submissions from multiple disciplines and different methodological approaches from scholars around the world. In addition to individual paper submissions, the journal also welcomes proposals for special symposia (3-5 articles) on specific regional or disciplinary themes. All symposia will undergo the same peer review process as other articles. Articles should be between 8,000 and 10,000 words in length (including notes and bibliography).

Inquiries. Direct all inquiries regarding articles and special symposia to the Editor: florian.bieber@uni-graz.at.

Electronic Submission. All submissions should be made online at the Nationalities Papers ScholarOne Manuscripts site (http://mc.manuscriptcentral.com/CNAP). New users should first create an account. Once a user is logged onto the site submissions should be made via the Author Centre. Authors should prepare and upload two versions of their manuscript. One should be a complete text, while in the second all document information identifying the author should be removed from files to allow them to be sent anonymously to referees. When uploading files authors will then be able to define the non-anonymous version as "File not for review".

Note to authors. Authors should be mindful of the need to identify and reference quoted material - text, tables, and figures - clearly and consistently, and to secure written permission from the copyright holder as appropriate. http://tandf.tandf.co.uk/journals/ethics.asp

Free article access. As an author, you will receive free access to your article on Taylor \& Francis Online. You will be given access to the My authored works section of Taylor \& Francis Online, which shows you all your published articles. You can easily view, read, and download your published articles from there. In addition, if someone has cited your article you will be able to see this information. We are committed to promoting and increasing the visibility of your article and have provided this guidance (http://journalauthors.tandf.co.uk/beyondpublication/ promotearticle.asp) on how you can help.

Reprints and journal copies. Corresponding authors will receive a complimentary copy of the issue containing their article. Reprints can be ordered through Rightslink ${ }^{\circledR}$ when proofs are received. If you have any queries about reprints, please contact the Taylor \& Francis Author Services team at reprints@tandf.co.uk. To order extra copies of the issue containing your article, please contact our Customer Services team at adhoc@tandf.co.uk.

Copyright. It is a condition of publication that all contributing authors grant to The Association for the Study of Nationalities the necessary rights to the copyright in all articles submitted to the Journal. Authors are required to sign an Article Publishing Agreement to facilitate this. This will ensure the widest dissemination and protection against copyright infringement of articles. The "article" is defined as comprising the final, definitive, and citable Version of Scholarly Record, and includes: $(a)$ the accepted manuscript in its final and revised form, including the text, abstract, and all accompanying tables, illustrations, data; and $(b)$ any supplementary material. Copyright policy is explained in detail at http://journalauthors.tandf.co.uk/preparation/copyright.asp.

Authors are themselves responsible for obtaining permission to reproduce copyright material from other sources. The editors accept no responsibility for the statements of fact or opinion made by the contributors.

For further information about Taylor \& Francis journals please visit www.tandfonline.com.

If you are unable to access our websites, please write to: Nationalities Papers, Editorial Department, Taylor \& Francis, 4 Park Square, Milton Park, Abingdon, Oxon, OX14 4RN, UK.

\title{
THE ASSOCIATION FOR THE STUDY OF NATIONALITIES
} New York

President

Vice-Presidents

Convention Director:

Executive Director:

Treasurer:

Chair of the Advisory Board:

Communications Officer:

Editor, Nationalities Papers:

Member at-Large:

Executive Committee:
Phone: +1 2128546239

Zsuzsa Csergo, Queen's University, Canada

Vejas Liulevicius, University of Tennessee, USA

Florian Bieber, University of Kent, UK

Dmitry Gorenburg, Senior Analyst, CNA

Harris Mylonas, George Washington University, USA

Dominique Arel

Lydia C. Hamilton

Julie George, Queens College, the City University of New York, USA

Sherrill Stroschein, University College London, UK

Lisa Koriouchkina, Brown University, USA

Peter Rutland, Wesleyan University, USA

Peter Vermeersch, University of Leuven, Belgium

Michael Rywkin, City College, USA (President Emeritus)

David Crowe, Elon University, USA (President Emeritus)

Stefano Bianchini, University of Bologna, Italy

Holly Case, Cornell University, USA

Nina Caspersen, Lancaster University, UK

Michele Commercio, University of Vermont, USA

Bhavna Dave, School of Oriental \& African Studies, UK

Elise Giuliano, Harriman Institute, Columbia University, USA

Alexandra Goujon, University of Bourgogne, Dijon, France

Henry Hale, George Washington University, USA

Alexandra Hrycak, Reed College, USA

Charles King, Georgetown University, USA

André Liebich, Graduate School of International Studies, Switzerland

Oxana Shevel, Tufts University, USA

Andreas Wimmer, Princeton University, USA

Stefan Wolff, University of Nottingham, UK
d online by Cambridge Unversity Press 


\section{Contents}

\section{Analysis of Current Events}

Analysis of current events: "towards the rule of law in Kosovo: EULEX should go"

Andrew Radin

Special Section: Border Communities: Microstudies on Everyday Life, Politics and Memory in

European Societies from 1945 to the present

Guest Editors: Libora Oates-Indruchová and Muriel Blaive

Border communities: microstudies on everyday life, politics and memory in European Societies

from 1945 to the present

Libora Oates-Indruchová and Muriel Blaive

Memories of ethnic cleansing and the local Iron Curtain in the Czech-German borderlands

Friederike Kind-Kovács

Nationalization campaigns and teachers' practices in Belgian-German and Polish-German

border regions (1945-1956)

Machteld Venken

The border as pain and remedy: commemorating the Polish-Ukrainian conflict of 1918-1919

in Lviv and Przemyśl

Tatiana Zhurzhenko

Between Russia and Estonia: narratives of place in a new borderland

Alena Pfoser

\section{Articles}

Contextualized violence: politics and terror in Dagestan

Magomed-Rasul Ibragimov and Kimitaka Matsuzato

Minorities and marginality: pertinacity of Hindus and Sikhs in a

repressive environment in Afghanistan

Hafizullah Emadi

From local to global: transformations of Bukharan Jewish community organization in the twentieth century

Zeev Levin

Whose land is it? Land reform, minorities, and the titular "nation" in Kazakhstan, Kyrgyzstan, and Tajikistan Brent Hierman and Navruz Nekbakhtshoev

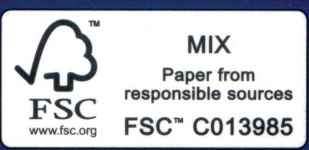

